\title{
Sistem Penerimaan Siswa Berbasis Web di SMK Spes Patriae
}

\author{
Dhani Fajar Driantama1), Harfebi Fryonanda ${ }^{2)}$ \\ Sistem Informasi, Fakultas Industri Kreatif Kalbis Institute \\ Jalan Pulomas Selatan kav.22, Jakarta Timur 13210 \\ 1)Email:dhani17fajar@yahoo.com \\ 2)Email: harfebi.fryonanda@kalbis.ac.id
}

\begin{abstract}
Education is something that may be considered important by many people. The process of admission is the first step that is taken to get an education. Spes Patriae vocational high schools are one of the vocational schools that have some problems with the admission process of their students, such as data recording errors and queue that happened. The principal hopes the admissions process can be computerized so that the vision of this school for technological development can be more realized. System development method used in this research is prototype, with stages such as: (1) needs collection; (2) design of prototype; (3) development of prototype; (4) customer evaluation; (5) prototype fixes; and (6) system development. The end result of this research is a web-based admissions system in SMK Spes Patriae, which can minimize data recording errors and also avoid the queue that occurs during the admissions process.
\end{abstract}

Keywords: prototype, student admission system, Spes Patriae vocational high school, web

\begin{abstract}
Abstrak: Pendidikan merupakan hal yang mungkin dianggap penting oleh banyak orang. Proses penerimaan siswa adalah langkah pertama yang dilakukan untuk mengenyam pendidikan. SMK Spes Patriae merupakan salah satu SMK yang memiki beberapa permasalahan pada proses penerimaan siswanya, seperti kesalahan pencatatan data dan antrian yang terjadi. Kepala sekolah berharap proses penerimaan siswa dapat terkomputerisasi sehingga visi dari sekolah ini untuk perkembangan teknologinya dapat semakin terwujud. Metode pengembangan sistem yang digunakan dalam penelitian ini ialah prototype, dengan tahapan seperti : (1) pengumpulan kebutuhan; (2) perancangan prototype; (3)pembangunan prototype; (4)evaluasi customer; (5) perbaikan prototype; dan (6) pembangunan sistem. Hasil akhir dari penelitian ini ialah sistem penerimaan siswa berbasis web di SMK Spes Patriae, yang dapat meminimalisir kesalahan pencatatan data dan juga menghindari antrian yang terjadi saat proses penerimaan siswa.
\end{abstract}

Kata kunci: prototype, sistem penerimaan siswa, SMK Spes Patriae, web

\section{PENDAHULUAN}

Pendidikan merupakan hal yang mungkin dianggap penting oleh banyak orang. Indonesia memiliki beberapa jenjang pendidikan yaitu PAUD, TK, SD, SMP, SMA, SMK, dan perguruan tinggi [1]. Meskipun berada pada tingkatan yang sama namun SMK berbeda dengan SMA, karena SMK lebih berfokus untuk menciptakan lulusan siap kerja dengan adanya praktek kerja lapangan (PKL). Pendidikan tingkat SMK sudah tersebar banyak didaerah Indonesia dengan jumlah 13.236 sekolah [2]. Salah satu sekolahnya yaitu SMK Spes Patriae yang berada di Jakarta Utara. Sekolah ini merupakan sekolah swasta yang dinaungi oleh sebuah yayasan yaitu yayasan Paroki Santo Lukas Penginjil. Sekolah ini juga sudah mendapatkan akreditasi Adengan nilai 94, dimana sekolah ini sudah memiliki fasilitas yang modern seperti salah satunya adalah fingerprint scanner, yang digunakan untuk para siswa melakukan absensi.

SMK Spes Patriae memiliki sebuah visi yang menjadi tujuannya untuk dicapai. Visinya adalah menyiapkan tamatan yang cerdas, terampil, jujur, profesional, yang dilandasi iman, takwa, dan perkembangan teknologi. Kendati demikian, pada kenyataan yang ada khususnya untuk perkembangan teknologi, sekolah ini hanya baru memanfaatkan teknologi fingerprint scanner untuk sistem absensi [3]. Sementara itu untuk hal yang masih memiliki beberapa kekurangan dan kendala, seperti sistem penerimaan siswa yang masih bersifat manual, belum dilakukan pemanfaatan teknologinya. Sistem penerimaan siswa SMK ini terdiri dari sistem penerimaan siswa baru dan siswa pindahan. Kepala Sekolah SMK ini berharap supaya sistem penerimaan ini dapat terkomputerisasi, sehingga data yang 
diperlukan dapat langsung diisi oleh calon pendaftar itu sendiri.

Berdasarkan dari penelitian terdahulu, ada beberapa permasalahan yang umum terjadi dalam sistem penerimaannya yang masih manual diantaranya yaitu: (1) kesalahan pencatatan data [4]observasi dan studi pustaka. Tahap kedua adalah perancangan sistem dengan UML Diagram (Use Case Diagram, Activity Diagram, Sequence Diagram dan Class Diagram; (2) prosedur pendaftaran yang lama [5]; (3) terjadinya antrian yang memakan waktu terlebih saat banyaknya calon pendaftar yang datang [6]; (4) cangkupan wilayah yang terbatas, sehingga tidak meratanya cangkupan informasi pendaftaran untuk para calon pendaftar yang berada di luar cangkupan wilayahnya [7]. Permasalahan serupa juga terjadi di SMK Spes Patriae, dimana permasalahannya yaitu adanya data miss, seperti kesalahan pencatatan data, dan proses pengantrian yang bisa memakan waktu lama, dimana seringkali banyak calon pendaftar yang banyak bertanya, dan terkadang setelah bertanya banyak, ada juga yang tidak jadi untuk melakukan pendaftarannya, sehingga waktu terbuang percuma.

Berdasarkan permasalahan di atas, peneliti dapat menyimpulkan bahwa permasalahan tersebut dapat diselesaikan dengan sistem berbasis web untuk penerimaan siswa baru dan siswa pindahan yang dapat mengindari terjadinya antrian dan mengurangi terjadinya kesalahan pencatatan data. Sehingga peneliti menyusun penelitian ini dengan judul "Sistem Penerimaan Siswa Berbasis Web di SMK Spes Patriae". Metode yang digunakan oleh Peneliti dalam mengembangan sistem ini adalah prototype. Prototype digunakan oleh peneliti karena sistem yang dikembangkan oleh peneliti merupakan sistem dengan skala kecil, yang mana cocok dengan metode prototype. Metode prototype juga dapat menghemat waktu yang digunakan untuk pengembangan terhadap sistemnya, dimana koreksi yang dilakukan dalam metode ini dilakukan hanya dengan menunjukan prototype yang dibuat untuk diminta feedback dari user. Koreksi yang dilakukan lebih mudah karena tidak perlu merombak sistem secara keseluruhan, dan juga dengan adanya interaksi yang terjadi peneliti dapat mengetahui lebih detail apa yang diinginkan oleh user dari sistem yang telah dibuat, sehingga sistem yang dibuat tidak jauh dari harapan user.

\section{METODE PENELITIAN}

\section{A. Alur Penelitian}

Alur penelitian berisi langkah-langkah yang dilakukan oleh peneliti dalam melakukan penelitian ini. Alur penelitian pada penelitian ini dilakukan berdasarkan dari metode pengembangan sistem prototype yang peneliti gunakan. Peneliti melakukan beberapa tahapan yang ada dalam metode pengembangan sistem dalam penelitian ini. Metode pengembangan sistem prototype memiliki beberapa tahapan yang terdiri dari: (1) requirement gathering (pengumpulan kebutuhan) yang dilakukan dengan wawancara ataupun observasi; (2) perancangan prototype yang dilakukan dengan menggambarkan rancangan sistem dalam bentuk diagram maupun mockup tampilan; (3) pembangunan prototype dilakukan dengan membangun simulasi berupa tampilan yang interaktif dari sistem yang dibangun; (4) evaluasi prototype dilakukan dengan mendemonstrasikan prototype ke user, yang kemudian dilakukan evaluasi atas feedback yang didapat dari user, perbaikan kemudian dimulai lagi dari tahapan perancangan prototype; (5) pembangunan sistem dilakukan dengan membangun sistem secara keseluruhan yang sudah dinamis dimana data-data yang ada sudah dapat dikelola [8].

Tahapan penelitian yang dilakukan peneliti dimulai dari analisa masalah, studi literatur, requirement gathering (pengumpulan kebutuhan), perancangan prototype, pembangunan prototype, evaluasi prototype, pembangunan sistem, dan terakhir pengujian sistem.

Tiap tahapan yang ada memiliki input dari data yang dimasukan dalam tahapan, proses yang dilakukan pada tahapan tersebut untuk mengelola data input, dan output yang merupakan hasil dari input yang telah diproses pada tahapan tersebut. Tiap output yang dihasilkan dari tahapan-tahapan yang ada, digunakan menjadi input pada tahapan selanjutnya. Tahapan-tahapan berikut dengan input, proses, output yang terdapat di tiap tahapannya, peneliti gambarkan melalui diagram yang dapat dilihat pada Gambar 1 .

\section{Analisa Masalah}

Pada tahapan ini peneliti melakukan observasi secara langsung pada SMK Spes Patriae, dan wawancara kepada Kepala Sekolah SMK Spes Patriae, dan ketua panitia PMB (Penerimaan Murid Baru). Peneliti melakukan ini untuk dapat mengetahui masalah mengenai prosedur penerimaan siswa.

Dari hasil wawancara dan observasi yang dilakukan oleh peneliti, didapatkanlah beberapa permasalahan yang terjadi dalam proses penerimaan siswanya. Permasalahannya diantaranya adalah seperti kesalahan pencatatan data. Hal ini disebabkan karena pencatatan dilakukan menggunakan kertas manual saat pendaftar datang untuk mendaftar 


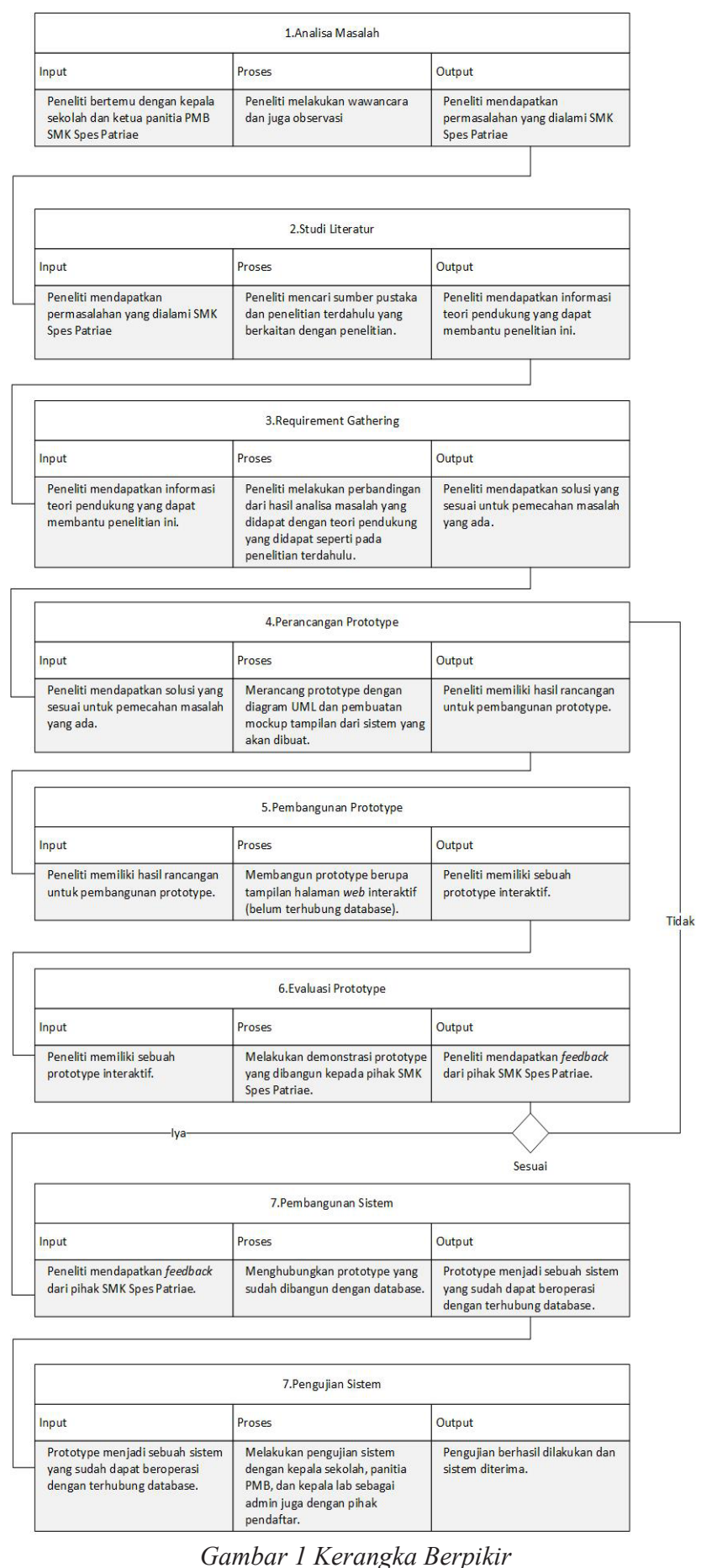

pertama kalinya. Selain itu juga banyaknya pendaftar yang hadir serta banyaknya data pendaftar yang ada menyebabkan kesalahan pencatatan data ini sangat mungkin terjadi.

Permasalahan kedua yang berhasil peneliti dapatkan dari hasil wawancara dan observasi ini adalah terjadinya antrian pada saat proses penerimaan siswa. Antrian yang terjadi dapat memakan waktu lama, khususnya saat proses wawancara dan negoisasi dengan panitia PMB. Para pendaftar seringkali banyak mengajukan pertanyaan-pertanyaan pada panitia PMB mengenai sekolah ini, khususnya untuk biaya dan negoisasi, sehingga memakan waktu yang banyak. Bahkan tidak jarang pendaftar yang sudah mengajukan banyak pertanyaan ini tidak jadi mendaftar karena beberapa hal, seperti salah satunya ialah tidak adanya kesepakatan negoisasi.

\section{Studi Literatur}

Pada tahap ini peneliti melakukan studi literatur dengan mencari teori pendukung melalui buku-buku referensi yang didapat dari perpustakaan, internet yang memiliki sumber data yang valid. Jurnaljurnal referensi juga penelitian terdahulu kemudian juga dijadikan sebagai acuan dalam melakukan penelitian ini, sehingga instrument penelitian ini dapat menyelesaikan permasalahan penerimaan siswa yang terdapat pada SMK Spes Patriae. Buku-buku yang peneliti gunakan merupakan buku-buku yang berkaitan langsung dengan topik dari penelitian yang peneliti sedang lakukan, begitu juga dengan jurnal yang didapatkan oleh peneliti, seperti jurnal penelitan terdahulu. Jurnal penelitian terdahulu yang peneliti gunakan adalah jurnal penelitian yang memiliki kasus permasalahan yang sama dengan yang dialami oleh objek penelitian ini.

\section{Requirement Gathering}

Berdasarkan informasi yang didapat dari wawancara, dan observasi peneliti melakukan perbandingan dengan studi literatur terutama penelitian terdahulu yang peneliti dapatkan. Peneliti kemudian mulai mengumpulkan setiap hal-hal yang diperlukan dalam penelitian ini. Peneliti memutuskan untuk membuat suatu sistem berbasis web berdasarkan requirement yang telah didapat, termasuk dari hasil perbandingan yang dilakukan oleh peneliti terhadap penelitian terdahulu. Sistem ini dibuat peneliti untuk membantu para pendaftar SMK Spes Patriae, agar tidak perlu repot-repot lagi untuk datang dan mengantri untuk melakukan pendaftaran.

\section{Perancangan Prototype}

Peneliti mulai membuat suatu rancanganrancangan berdasarkan kebutuhan user. Rancangan ini digunakan dalam membangun suatu prototype, dengan menggambarkan beberapa rancangan prototype dengan diagram UML (Unified Modeling Language) dan desain mockup tampilan website pada tiap halaman website. Diagram UML merupakan suatu perangkat utama dalam melakukan analisis dan perancangan sistem berorientasi objek. UML ini digunakan untuk menspesifikasi, memvisualisasi, dan mengontruksi pondasi dari software sistem, termasuk melibatkan pemodelan aturan-aturan bisnis, atau lebih singkatnya UML merupakan metode pengembangan perangkat lunak dengan metode penggambaran berbentuk grafis yang relatif mudah dipahami. Diagram UML yang peneliti gunakan 
untuk pembuatan rancangan prototype ini diantaranya adalah usecase diagram, activity diagram, sequence diagram, dan class diagram [9]. Mockup yang berupa tampilan dari tiap halaman dalam website, dirancang oleh peneliti menggunakan software balsamiq.

\section{Pembangunan Prototype}

Prototype dibuat berdasarkan dari semua kebutuhan dan juga rancangan yang telah dibuat oleh peneliti mengenai sistem yang akan dibangun. Baik itu rancangan dari diagram UML dan juga rancangan tampilan dari mockup yang dibuat oleh peneliti. Dalam proses ini dilakukan pembangunan sistem dilakukan dengan menggunakan bahasa pemrograman HTML (Hypertext Markup Language), yang merupakan bahasa pemrograman standard yang digunakan untuk memberikan tampilan pada halaman website [10]. CSS (Cascading Style Sheet) juga digunakan sebagai bahasa pemrograman yang untuk mengubah format tampilan halaman web, dengan mempercantik tampilan halaman pada website yang dibangun ini [11].

Tampilan dalam website yang dibuat oleh peneliti juga dijadikan lebih responsif lagi, sehingga nantinya website ini dapat diakses dengan nyaman melalui berbagai device selain komputer ataupun laptop, seperti smartphone, ataupun tablet. Hal ini dilakukan peneliti dengan menggunakan framework front-end open source yaitu bootstrap [12]. Namun website yang dibangun pada tahapan ini belum terhubung dengan database. Database sendiri merupakan suatu himpunan data yang telah dikelompokan dan terhubung satu sama lain, yang disimpan secara bersama tanpa pengulangan, dan diatur sedemikian rupa sehingga kelak dapat digunakan kembali dengan cepat dan mudah untuk memenuhi berbagai kebutuhan [13]. Oleh karena website ini belum terhubung dengan database, maka tentu website ini belum dinamis karena data-data yang ada didalamnya belum dapat untuk dikelola secara langsung, tetapi website yang dibangun pada tahapan ini sudah bersifat interaktif.

\section{Evaluasi Prototype}

Hasil dari prototype yang sudah dibangun kemudian didemonstrasikan kepada user pada tahapan ini. Dari demonstrasi yang dilakukan didapatkan beberapa evaluasi terhadap prototype yang sudah dibangun oleh peneliti. Evaluasi dilakukan oleh peneliti sampai mencapai kesepakatan dengan pihak SMK Spes Patriae, untuk kemudian dibangun sistem yang sudah sesuai. Ketika hasil dari prototype ini tidak disetujui oleh SMK Spes Patriae, maka peneliti akan memperbaiki mulai dari rancangan prototype yang sudah dibangun ini. Kemudian dari rancangan yang baru tersebut dilakukan pembangunan dan evaluasi kembali, sampai prototype disepakati oleh pihak SMK Spes Patriae yang bersangkutan. Setelah prototype sudah disepakati barulah langkah selanjutnya dilakukan.

\section{Pembangunan Sistem}

Setelah prototype yang ada sudah disepakati oleh pihak SMK Spes Patriae, peneliti mulai membangun sistem yang sesungguhnya, dimana prototype yang ada dilengkapi lagi dengan dihubungkannya database pada prototype yang sudah dibangun. Dalam menghubungkan prototype yang sudah dibangun ini dengan database, peneliti menggunakan MySQL yang merupakan sebuah software database open source yang pertama kali didukung oleh PHP (Personal Home Page) [14]. PHP itu sendiri merupakan suatu bahasa pemrograman yang dapat digunakan untuk membuat sebuah aplikasi yang lengkap untuk pembuatan laporan, seperti menghasilkan laporan dalam bentuk teks. PHP ini mendukung banyak database, sehingga website yang telah dibangun dapat menggunakan data dari database dengan sangat mudah [15].

\section{Pengujian Sistem}

Sistem yang sudah jadi kemudian dilakukan pengujian, dimana sistem akan diuji menggunakan pengujian black box testing. Pengujian black box yang dilakukan ini meliputi pengujian fungsionalitas program, tanpa melibatkan pengetahuan tentang internal aplikasi (source code dan sebagainya). Dalam black box testing penguji hanya mengetahui tentang input dan hasil output apa yang diharapkan dari fungsionalitas program, penguji tidak harus mengerti tentang kode pemrograman ataupun bagian internal aplikasi lainnya [16].

Pihak yang terlibat untuk menjadi penguji dalam black box testing selain peneliti sendiri ialah pihak dari SMK Spes patriae yang bersangkutan, yaitu ketua panitia PMB, kepala sekolah, admin, dan juga pendaftar. Pada tahap ini sistem didemonstrasikan oleh peneliti kepada pihak-pihak tersebut, dimana setelah selesai dilakukan demonstrasi sistem. peneliti meminta pendapat dari pihak yang bersangkutan tersebut melalui selebaran yang berisi pertanyaan untuk hasil pengujian dan penerimaannya. Hal ini dilakukan untuk mengetahui apakah sistem yang sudah jadi ini sudah sesuai dengan ekspektasi dan dapat berjalan dengan baik atau masih terdapat error ataupun bug. Ketika sistem yang dibangun ini masih memiliki beberapa permasalahan seperti error ataupun bug, peneliti melakukan perbaikan terhadap bug ataupun error yang ada tersebut. 


\section{HASIL DAN PEMBAHASAN}

\section{A. Perancangan Prototype}

Pada tahapan ini dilakukan beberapa perancangan sistem usulan dari sistem yang sedang berjalan pada SMK Spes Patriae seperti berikut ini :

\section{Sistem Berjalan}

Berikut ini pada Gambar 2. merupakan alur dari sistem penerimaan siswa yang sedang berjalan pada SMK Spes Patriae, yang digambarkan melalui activity diagram.

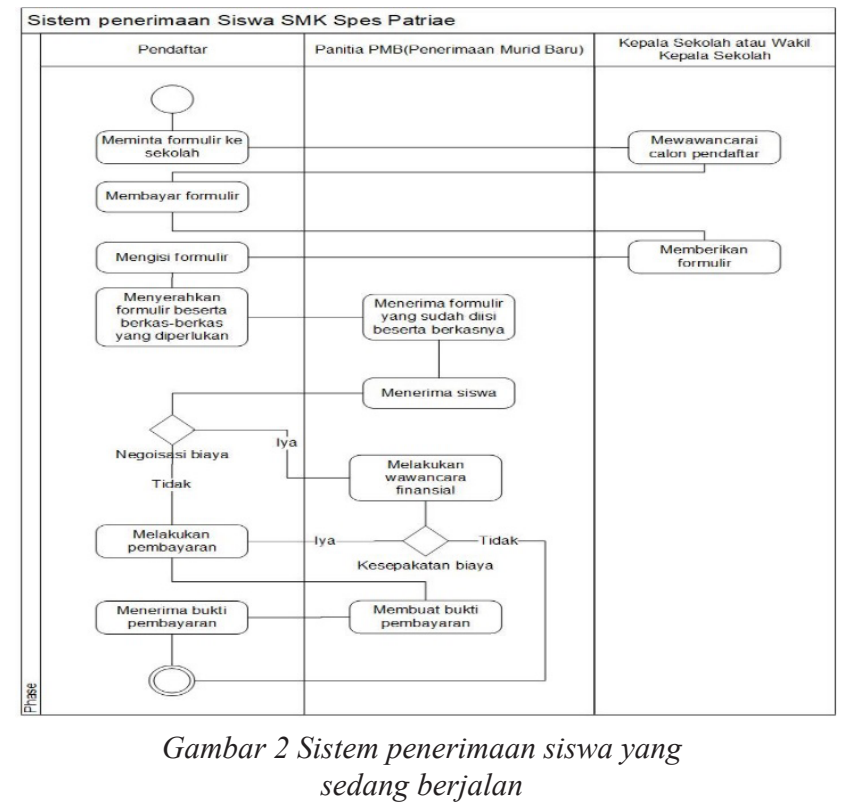

Berdasarkan dari penggambaran activity diagram tersebut, berikut ini merupakan penjelasannya : (1). Calon pendaftar datang ke SMK Spes Patriae untuk meminta formulir; (2). Dilakukan wawancara oleh kepala sekolah, apabila calon pendaftar tersebut adalah siswa pindahan maka akan dilihat dulu apakah sebelumnya dia sudah naik kelas atau tidak naik kelas, karena SMK Spes Patriae tidak menerima siswa naik terbang (siswa yang di sekolah asalnya tidak naik kelas tetapi meminta untuk lanjut kelas atau dinaikan); (3). Calon pendaftar membayar sejumlah uang untuk formulirnya; (4). Kepala sekolah kemudian memberikan formulir kepada calon pendaftar; (5). Calon pendaftar dapat membawa pulang formulir untuk diisi; (6). Calon pendaftar menyerahkan formulir yang sudah diisi kepada panitia PMB; (7). Panitia PMB mengambil formulir yang sudah diisi dan kemudian melakukan penerimaan terhadap pendaftarnya; (8). Calon pendaftar bisa melakukan negoisasi biaya ataupun tidak, sesuai dengan kemampuan finansial dari calon pendaftar; (9). Panitia PMB akan melakukan wawancara finansial untuk proses negoisasi biayanya; (10). Apabila tidak tercapai suatu kesepakatan maka pendaftaran dapat dibatalkan, tetapi apabila tercapai suatu kesepakatan proses pendaftaran dapat dilanjutkan; (11). Calon pendaftar melakukan pembayaran sesuai dengan biaya yang telah disepakati; (12). Panitia PMB membuat bukti pembayaran untuk calon pendaftar; dan (13). Calon pendaftar dapat membawa pulang bukti pembayaran yang telah dilakukan.

\section{Sistem Usulan}

Perancangan dalam penggambaran sistem usulan ini menggunakan diagram UML (Unified Modeling Language) yang terdiri dari usecase diagram, activity diagram, sequence diagram, dan class diagram :

\section{a. Usecase Diagram}

Usecase diagram menjelaskan keterhubungan tiap user dengan interaksi yang dilakukan pada sistem yang akan dibuat [17], seperti pada Gambar 3.

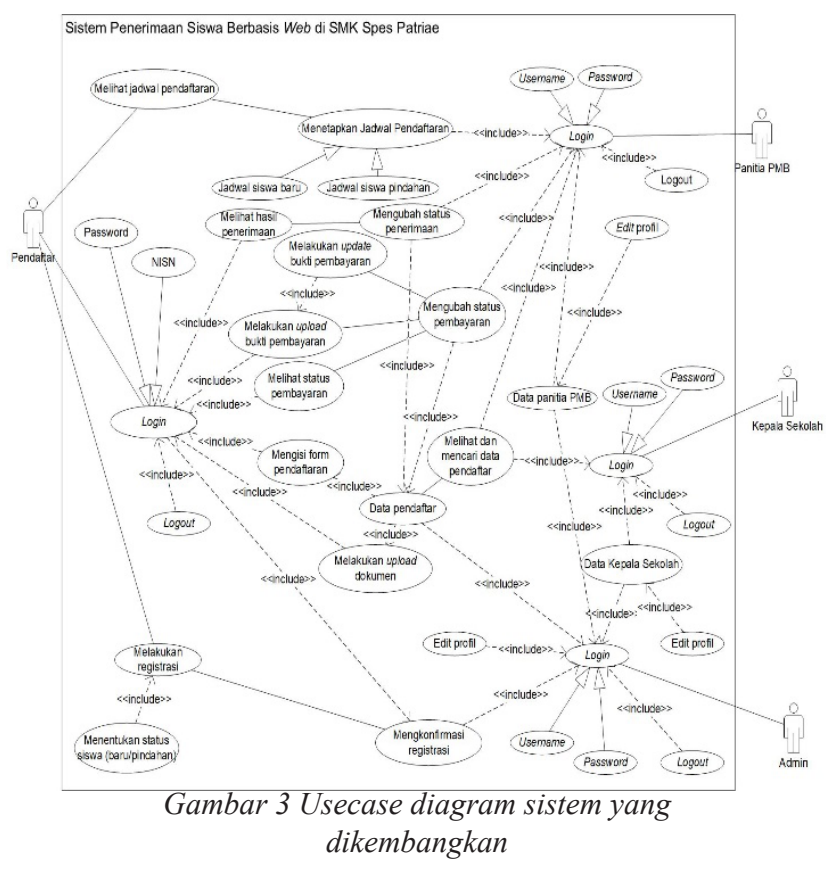

Pada Gambar 3 dapat dilihat bahwa tiap aktor yaitu pendaftar, panitia PMB (Penerimaan Murid Baru), kepala sekolah, dan admin memiliki akses untuk melakukan login. Khusus pendaftar, untuk mendapat akses login harus terlebih dahulu melakukan validasi dari nomor validasi yang didapatkan melalui email setelah melakukan registrasi yang dapat dilakukan menyesuaikan jadwal pendaftaran yang ditetapkan panitia PMB.

Panitia PMB selain itu juga dapat melakukan perubahan profil seperti kepala sekolah, dan juga admin. Panitia PMB juga dapat melakukan konfirmasi pembayaran atas bukti pembayaran yang di upload pendaftar, dan konfirmasi penerimaan atas data pendaftar tersebut. Kepala sekolah dapat melihat 
laporan berupa list dan jumlah dari data pendaftar yang ada, dan admin disini memiliki fungsi untuk mengelola data dari para pendaftar, panitia PMB, dan kepala sekolah.

\section{b. Activity Diagram}

Activity diagram yang menggambarkan aktifitas dari suatu proses bisnis dalam sistem usulan yang akan dibangun [18], seperti pada Gambar 4.

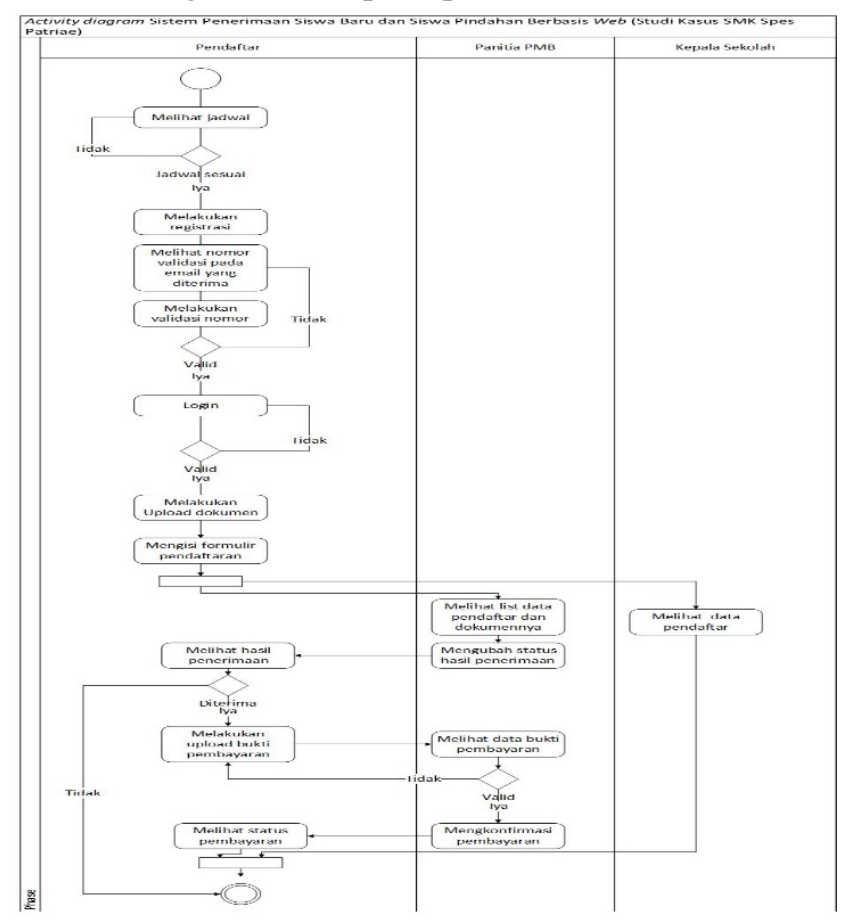

Gambar 4 Activity diagram sistem yang dikembangkan

Pada Gambar 4 dapat dilihat langkah-langkah dimana pendaftar pertama kali melihat jadwal apakah sesuai dengan jadwal pendaftaran untuk dapat melakukan registrasi. Setelah jadwal sesuai dan registrasi dapat dilakukan pendaftar melakukan validasi dari nomor yang diterima melalui email untuk dapat melakukan login. Setelah login pendaftar dapat melakukan upload dokumen yang diperlukan, kemudian mengisi forumulir yang disediakan. Setelah formulir selsai diisi dan dikirim maka data pendaftar dapat dilihat oleh kepala sekolah dan juga panitia PMB, dimana kemudian panitia PMB melakukan penerimaan terhadap pendaftar tersebut. Ketika status penerimaan pendaftar diterima maka pendaftar dapat melakukan upload bukti pembayaran yang apabila sudah valid maka dapat dikonfirmasi oleh panitia $\mathrm{PMB}$, dimana hasilnya dapat dilihat dalam status pembayaran.

\section{c. Sequence Diagram}

Sequence diagram yang menggambarkan interaksi ataupun perpindahan pesan yang dilakukan antar user dan juga sistem yang dibangun dimana masing-masing objek memiliki waktu hidup (lifeline). Dalam penggambaran diagram ini, objekobjek yang terlibat harus diketahui terlebih dahulu, beserta metode-metode yang dimiliki oleh kelas yang diinstansiasi menjadi objek itu berdasarkan dari usecase diagram yang telah dibuat. Selain itu juga perlu untuk melihat skenario yang ada pada use case saat penggambaran sequence diagram ini. Berikut ini merupakan rancangan sequence diagram yang dibuat oleh peneliti mengenai sistem yang dikembangkan.

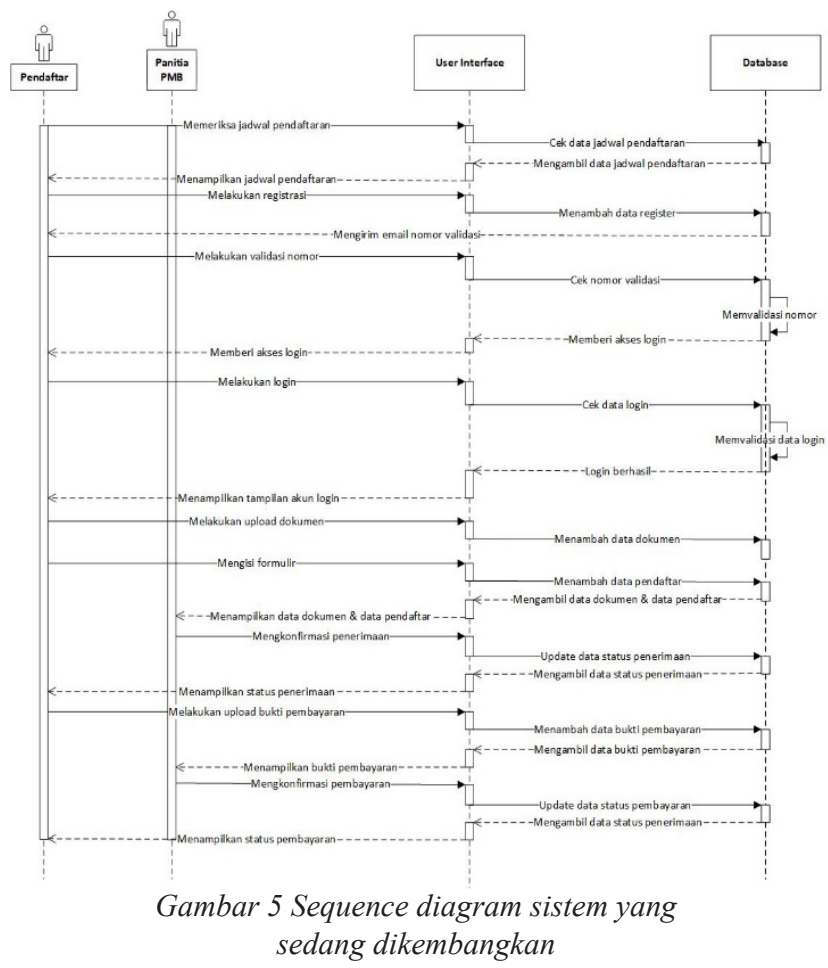

Pada Gambar 5 dapat dilihat bahwa pendaftar memeriksa jadwal pendaftaran sesuai dengan statusnya pada sistem, kemudian ditampilkan jadwal pendaftaran siswa baru dan siswa pindahan dari database. Pendaftar lalu melakukan registrasi, yang kemudian setelah email berisi nomor validasi diterima pendaftar melakukan validasi. Setelah melakukan validasi pendaftar dapat melakukan login, untuk kemudian melakukan upload dokumen yang setelahnya dapat dilakukan pengisian formulir. Setelah formulir di-submit, panitia melihat data pendaftar tersebut berikut dengan dokumennya yang ditampilkan dari database untuk melakukan konfirmasi penerimaan. Setelah hasil konfirmasi status penerimaan tersebut "Diterima" maka pendaftar melakukan upload bukti pembayaran, yang nantinya untuk dilihat oleh panitia PMB dalam menentukan status pembayarannya. Status pembayaran dapat dilihat oleh pendaftar pada halaman home setelah melakukan login.

Pada Gambar 6 dapat dilihat bahwa dalam sistem ini kepala sekolah dapat melakukan login, untuk melihat informasi mengenai data pendaftar, 


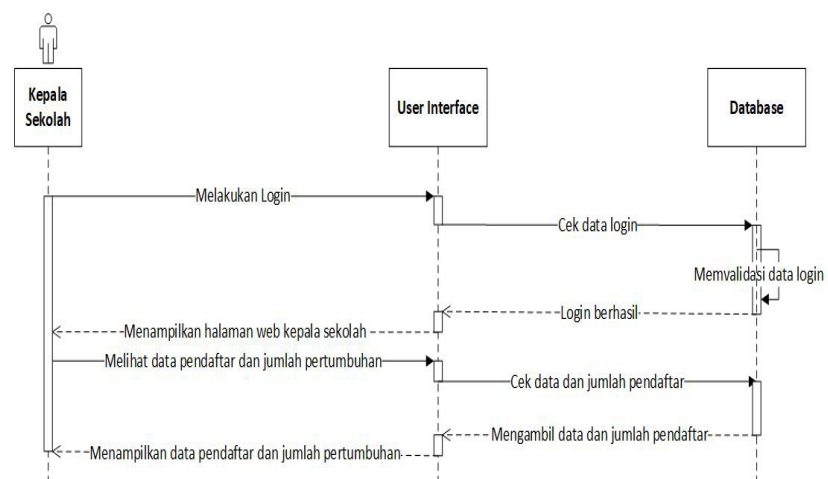

Gambar 6 Sequence diagram kepala sekolah

dan juga jumlah pertumbuhan pendaftar tersebut, yang kemudian akan ditampilkan oleh sistem dari database.

\section{d. Class Diagram}

Class diagram menggambarkan tiap-tiap kelas dalam sistem yang akan dibangun, beserta dengan atribut dan method yang dimilikinya. Atribut itu sendiri merupakan variabel-variabel yang dimiliki oleh kelas, sedangkan metode merupakan fungsi-fungsi yang dimiliki oleh kelas [19]. Class diagram yang dirancang sesuai dengan sistem yang dikembangkan oleh peneliti dapat dilihat pada Gambar 7.

Pada Gambar 7 dapat dilihat bahwa class register memiliki class dokumen dan class data pendaftar, yang mana data pendaftar itu memiliki beberapa bagian. Bagian class dari data pendaftar itu diantaranya seperti : (1) siswa baru; (2) siswa pindahan; dan. Class user terdiri dari panitia PMB dan

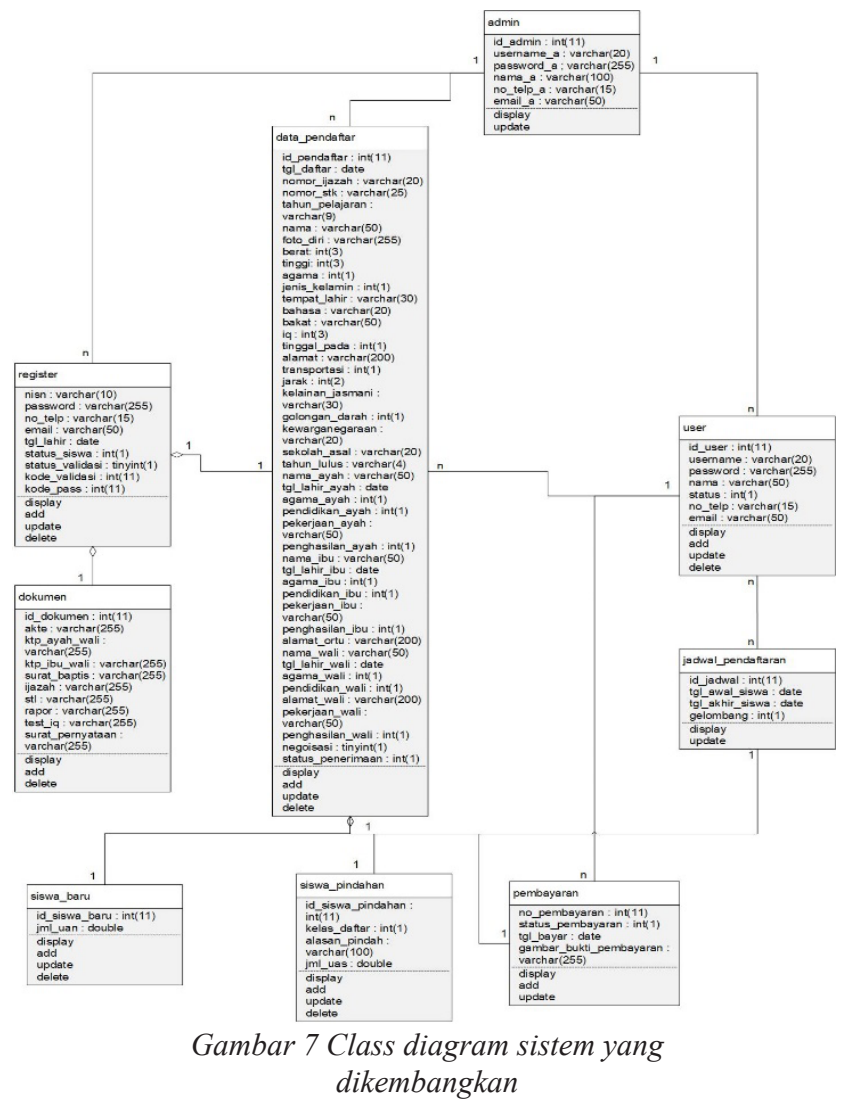

kepala sekolah berdasarkan status yang dimilikinya. Panitia PMB sebagai user disini berperan untuk menetapkan jadwal pendaftaran, status penerimaan dan status pembayaran dari pendaftar. Sedangkan kepala sekolah disini dapat melihat laporan dari data pendaftar yang ada. Admin memegang peranan terbesar seperti pada penggambaran class diagram, dimana admin mengatur data-data yang ada pada tabel user, pendaftar, dan registrasi.

\section{B. Pembangunan Prototype}

Pada tahap ini dilakukan pembangunan prototype yang dibuat berdasarkan dari semua kebutuhan dan rancangan yang telah dibuat oleh peneliti mengenai sistem yang akan dibangun. Pembangunan sistem untuk prototype ini dilakukan dengan menggunakan bahasa pemrograman HTML dan CSS dengan framework Bootstrap untuk membuat tampilan web menjadi responsive. Sistem yang dibangun pada tahapan ini belum terhubung dengan database namun sudah interaktif, sehingga user dapat tetap berinteraksi dengan sistem yang dibangun ini.

\section{Evaluasi Prototype}

Pada tahap ini, peneliti melakukan demonstrasi terhadap prototype yang telah dibangun kepada pihak SMK Spes Patriae. Dari hasil demonstrasi yang dilakukan didapatkan beberapa feedback yang peneliti terima untuk melakukan evaluasi terhadap sistem. Evaluasi yang dilakukan peneliti diantaranya seperti: (1) penambahan laporan jumlah pendaftar tiap tahun pelajaran untuk kepala sekolah yang sebelumnya tidak ada; (2) penambahan atribut pada formulir pendaftaran, yang sebelumnya hanya beberapa atribut saja; (3) perubahan dalam pengaturan jadwal pendaftaran siswa baru dan siswa pindahan, yang sebelumnya jadwal pendaftaran siswa pindahan memiliki gelombang pendaftaran diubah menjadi tidak ada. Feedback yang sudah didapatkan oleh peneliti tersebut kemudian dilakukanlah perbaikan lagi yang dimulai dari tahapan perancangan prototype. Hal ini dilakukan oleh peneliti sampai semua feedback yang sudah didapatkan tersebut selesai dikerjakan dan disepakati oleh pihak yang bersangkutan di SMK Spes Patriae.

\section{Pembangunan Sistem}

Tahap ini dilakukan oleh peneliti ketika prototype yang peneliti bangun sudah disepakati oleh pihak SMK Spes Patriae. Prototype tersebut kemudian peneliti hubungkan dengan database menggunakan MySQL sebagai software database, dan PHP sebagai 
bahasa pemrograman yang digunakannya. Database dihubungkan dengan prototype dengan tujuan untuk membuat sistem yang dibangun ini menjadi lebih dinamis, dimana data-data yang terdapat didalamnya dapat berubah sesuai dengan interaksi yang dilakukan. Interaksi yang dilakukan dalam sistem dapat berupa penambahan data, penghapusan data, perubahan data ataupun pencarian data yang ada.

Sistem penerimaan siswa yang telah dibangun oleh peneiliti ini memiliki beberapa tampilan seperti tampilan untuk menu utama yang dapat diakses langsung tanpa melakukan login, tampilan untuk pendaftar, kepala sekolah, panitia PMB, dan admin yang dapat diakses ketika sudah berhasil melakukan login. Berikut ini merupakan beberapa tampilan dari sistem yang dibangun peneliti.

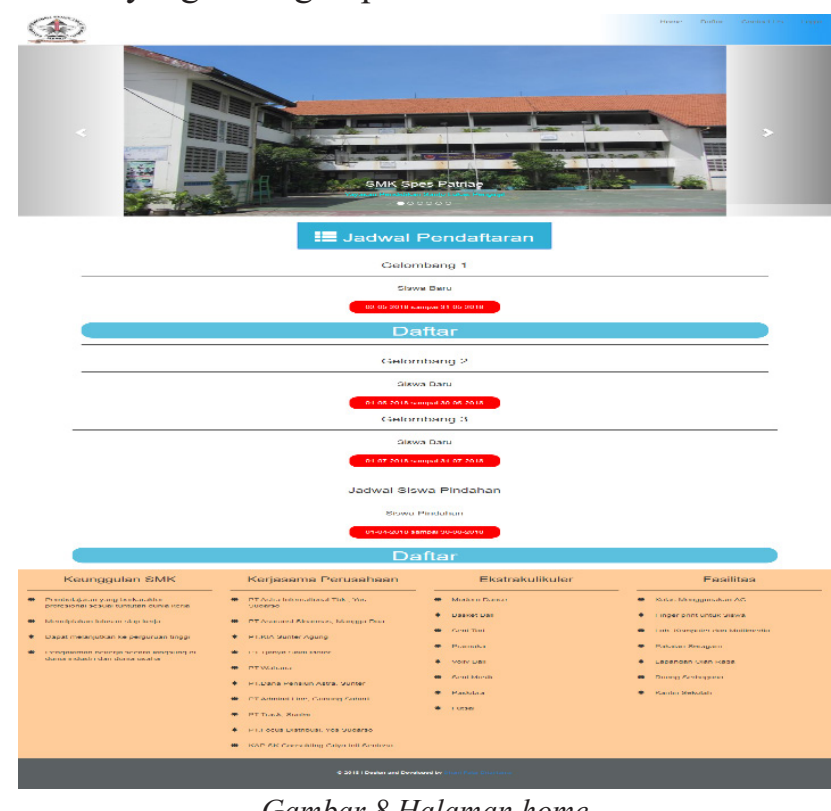

Gambar 8 Halaman home

Gambar 8 merupakan tampilan utama dari sistem yang dibangun peneliti. Pada bagian atas terdapat logo sekolah, dan menu-menu yang terdapat dalam website. Slider image menampilkan runtutan informasi sekolah yang berupa gambar, dan di bagian jadwal pendaftaran ditampilkan jadwal pendaftaran yang ada, dan tombol daftar muncul di bagian jadwal

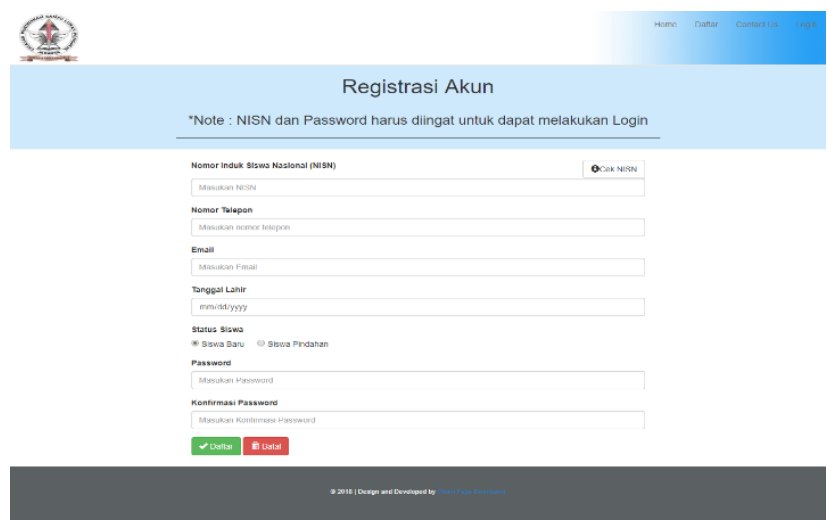

Gambar 9 Halaman daftar yang dibuka. Terakhir di bagian bawah terdapat informasi mengenai fasilitas dan keunggulan sekolah.

Gambar 9 merupakan halaman daftar, yang berisi form untuk pendaftar melakukan registrasi. Halaman ini hanya dapat dibuka saat jadwal pendaftaran dibuka.

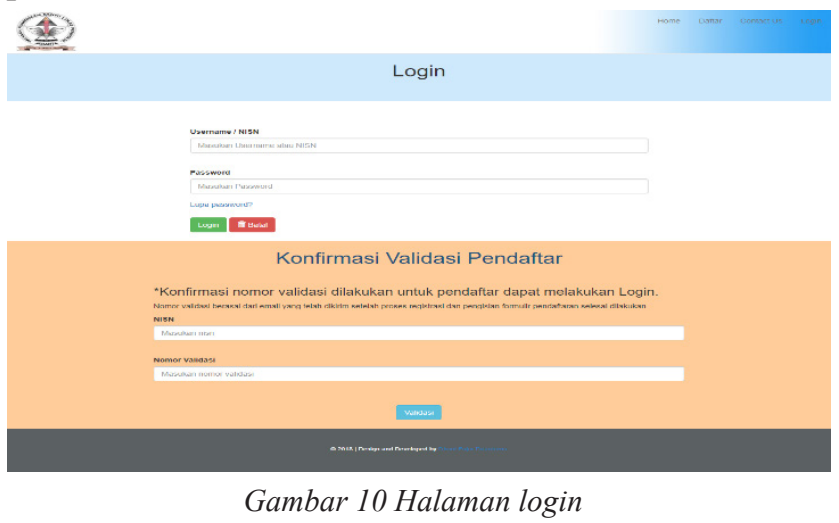

Gambar 10 merupakan halaman login yang berisi form untuk para user melakukan login dan konfirmasi validasi pendaftar, untuk pendaftar dapat melakukan validasi atas akun registrasinya melalui email yang didapat setelah registrasi dilakukan sehingga pendaftar dapat melakukan login.

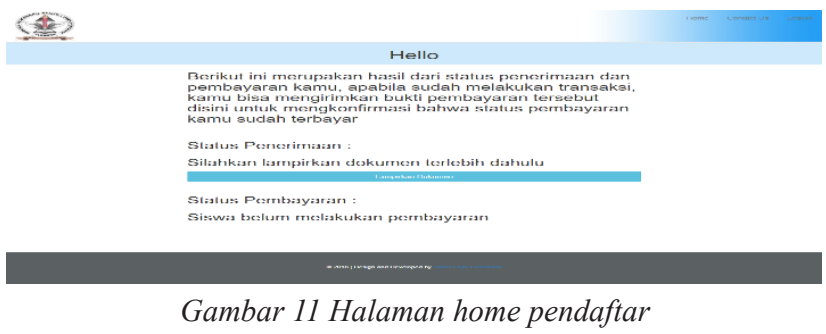

Gambar 11 merupakan halaman saat pertama kali pendaftar berhasil melakukan login. Pendaftar dapat melakukan beberapa hal sesuai dengan tombol yang muncul pada bagian status penerimaan dan status pembayarannya.

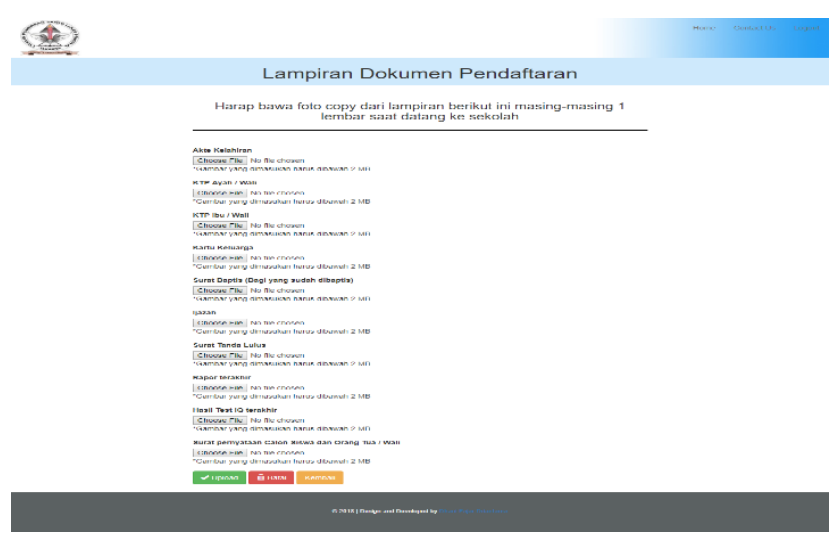

Gambar 12 Halaman upload dokumen

Gambar 12 merupakan tampilan dari halaman upload dokumen, yang diakses ketika tombol "Lampirkan dokumen" yang muncul pertama kali pada halaman seperti di Gambar 11 ditekan. Pada halaman ini pendaftar dapat memasukan dan 


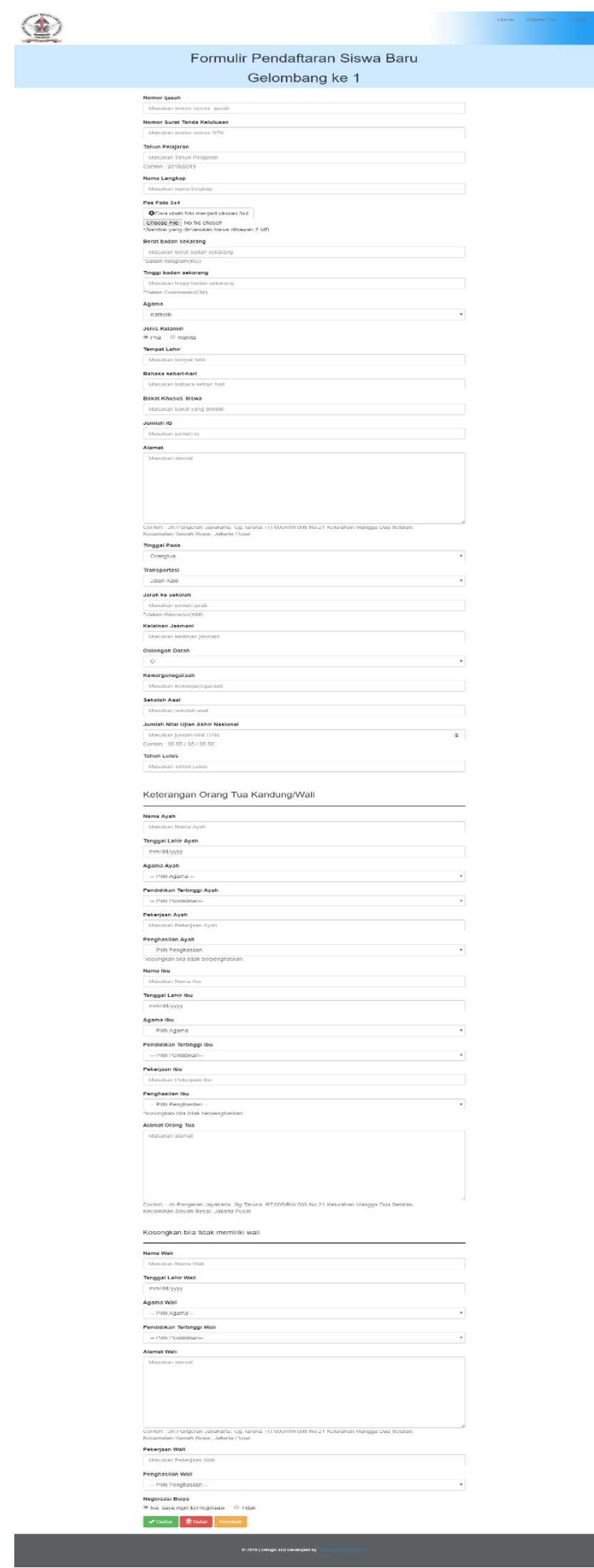

Gambar 13 Halaman formulir pendaftaran

melakukan upload dokumen yang sesuai dengan form yang ada.

Pada Gambar 13 merupakan halaman yang ditampilkan ketika tombol "Isi formulir" yang muncul setelah melakukan upload dokumen ditekan. Halaman ini berisi form-form sesuai dengan formulir pendaftaran yang ada, untuk diisi dan dikirim oleh pendaftar. Khusus untuk foto diri yang disisipkan pada formulir ini, terlebih dahulu jadikan foto diri yang ingin di-upload memiliki ukuran 3 x 4 sebelum dimasukan. Cara untuk merubah foto diri menjadi ukuran $3 \times 4$ dapat dilihat dengan menekan tombol "Cara ubah foto menjadi ukuran 3 x 4". Setelah semua data dalam formulir diisi, maka formulir dapat dikirimkan dengan menekan tombol "daftar". Data dari formulir yang dikirim ini kemudian akan diterima oleh panitia PMB untuk dilakukan penerimaan.

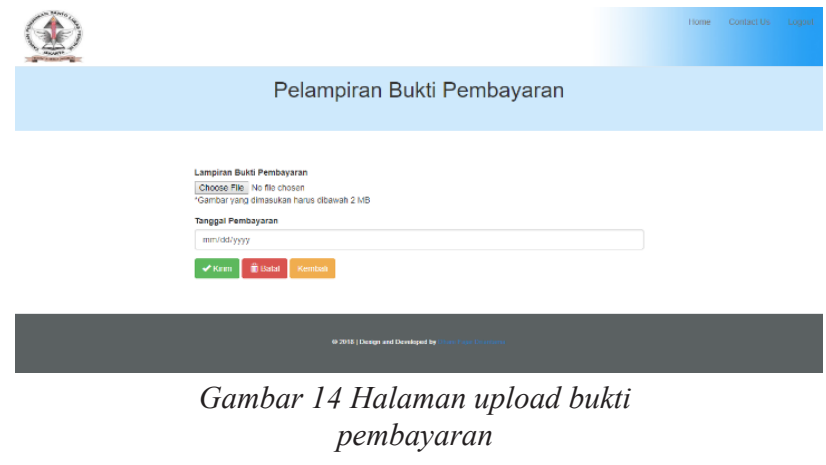

Gambar 14 merupakan tampilan form untuk pendaftar dapat melakukan upload bukti pembayaran. Halaman ini ditampilkan ketika tombol "Upload pembayaran" yang muncul setelah status penerimaan berubah menjadi "Diterima" ditekan. Status penerimaan berubah setelah panitia PMB melakukan konfirmasi terhadap data pendaftar yang sudah dikirim berdasarkan dari formulir dan dokumen yang ada, dimana email berisi pemberitahuan hasil penerimaan dikirimkan ke pendaftar. Setelah upload berhasil dilakukan maka pendaftar dapat melakukan update bukti pembayaran bila bukti pembayaran yang dikirim tidak valid, dimana halaman ini memiliki tampilan seperti Gambar 15.

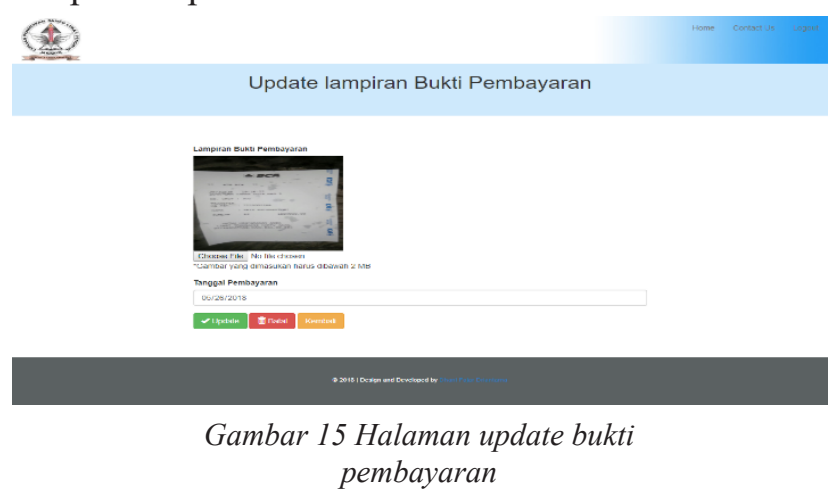

Gambar 16 merupakan halaman yang pertama kali ditampilkan setelah panitia PMB melakukan login. Pada halaman ini ditampilkan jadwal pendaftaran yang dapat diubah pada halaman seperti di Gambar 17, ketika tombol "Edit jadwal pendaftaran" yang terdapat dalam tiap bagian tombol (Gelombang 1/2/3 atau Jadwal pendaftaran) ditekan. Pada halaman ini 


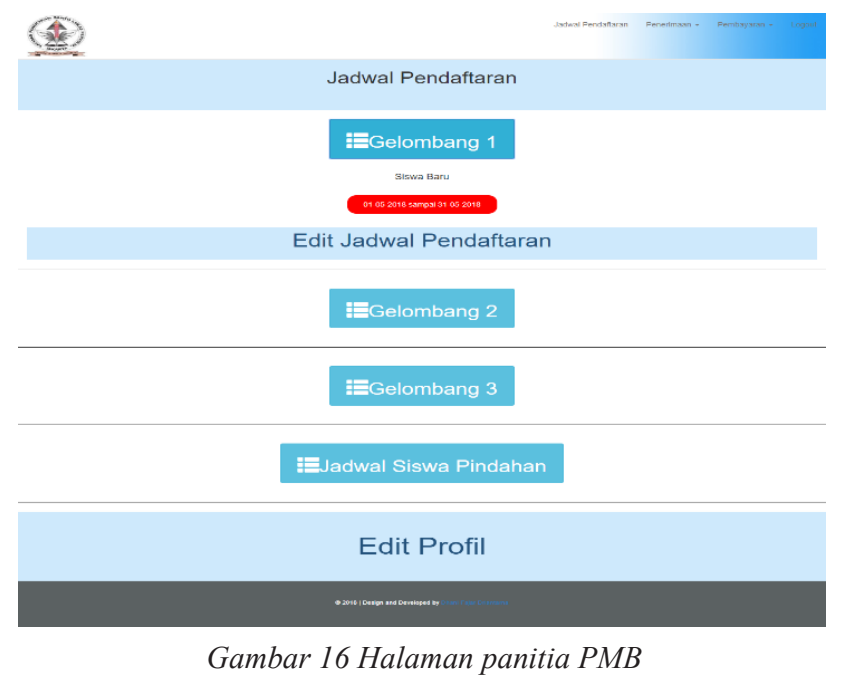

panitia PMB dapat menentukan jadwal pendaftaran dari tanggal awal dan tanggal akhir yang disediakan dalam form. Jadwal yang ditetapkan oleh panitia PMB inilah yang merupakan jadwal pendaftaran yang ditampilkan pada halaman home seperti di Gambar 8.
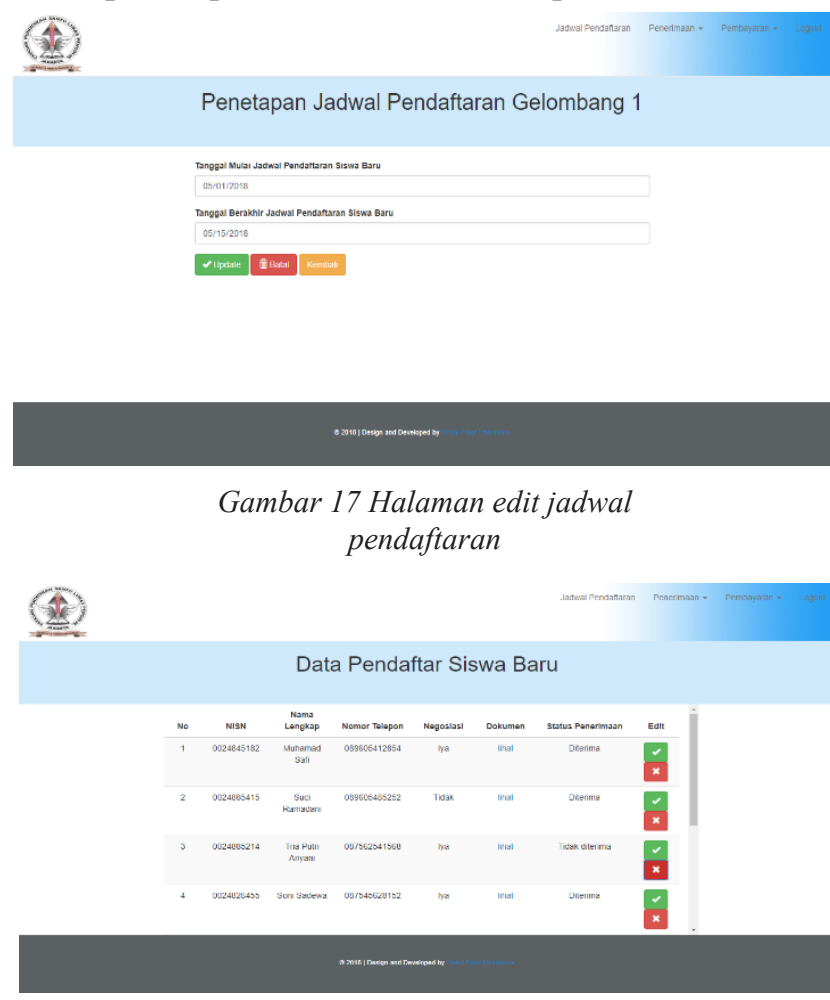

Gambar 18 Halaman penerimaan pendaftar

Gambar 18 merupakan halaman untuk panitia PMB dapat melakukan penerimaan. Tombol "centang" digunakan untuk menerima pendaftar tersebut, dan tombol "silang" untuk tidak menerima pendaftar tersebut. Ketika salah satu tombol tersebut ditekan, maka sistem akan mengirimkan email berisi pengumuman hasil penerimaan yang menyatakan pendaftar tersebut diterima atau tidak. Hasil pengumuman dalam email yang dikirim ke pendaftar menyesuaikan dengan tombol yang ditekan oleh panitia PMB tersebut.

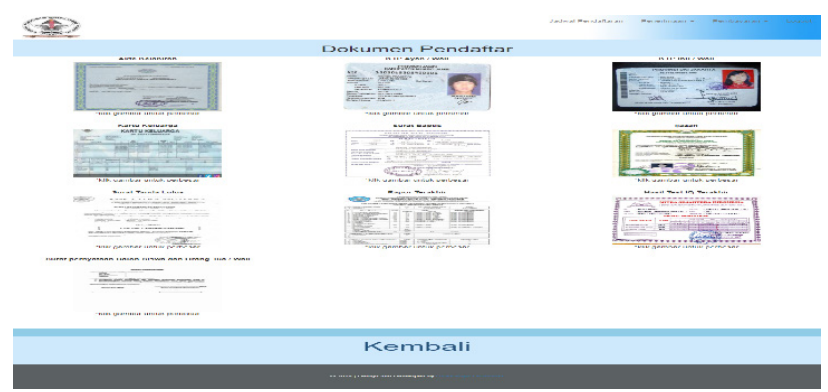

Gambar 19 Halaman list dokumen pendaftar

Gambar 19 merupakan halaman yang ditampilkan saat tombol "lihat" di kolom "Dokumen" pada Gambar 18 ditekan. Pada halaman ini panitia PMB dapat melihat keseluruhan dokumen yang telah di upload pendaftar tersebut.

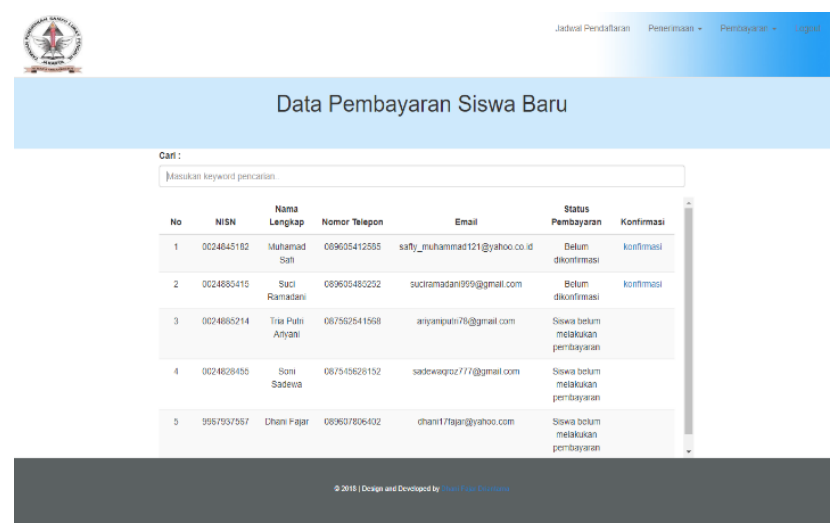

Gambar 20 Halaman data pembayaran siswa

Gambar 20 merupakan halaman dimana panitia PMB dapat melakukan konfirmasi pembayaran dengan mengubah status pembayaran yang dilakukan pada halaman seperti Gambar 21, dengan menekan

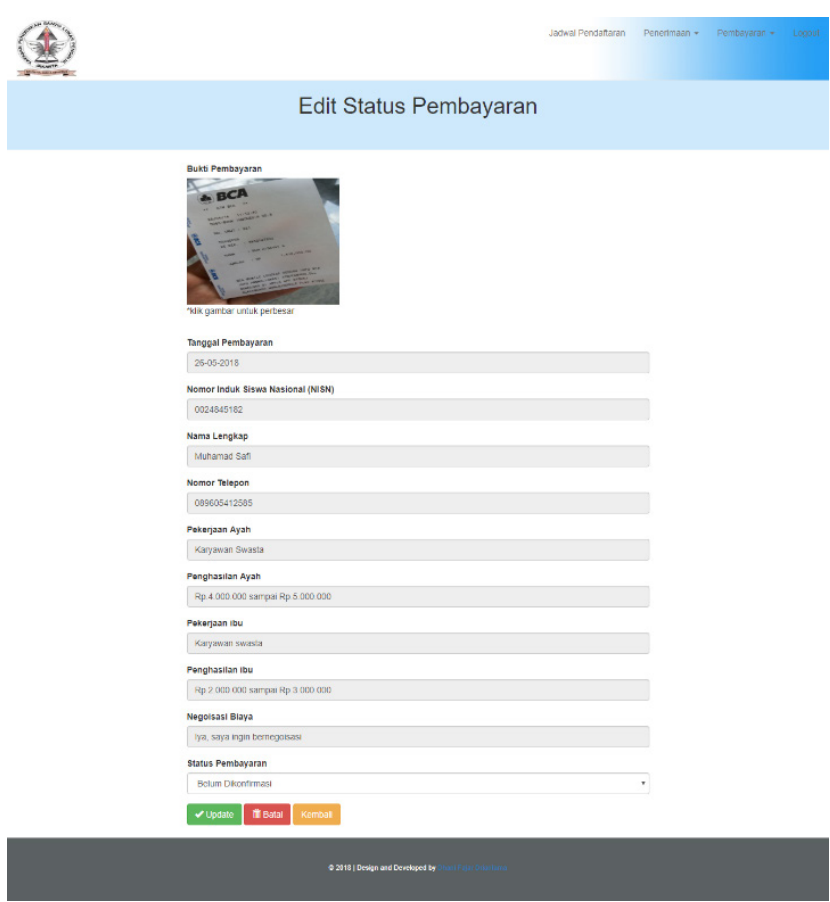

Gambar 21 Halaman edit status pembayaran 
tombol "konfirmasi" pada kolom "Konfirmasi" untuk masuk ke halaman ini. Status pembayaran diubah pada halaman ini dengan cara mengganti status pembayaran yang ada dalam form, kemudian menekan tombol update untuk melakukan perubahan terhadap status pembayaran dari pendaftar tersebut. Hasil dari perubahan status pembayaran pendaftar ini juga dapat dilihat oleh pendaftar melalui halaman home pendaftar seperti di Gambar 11.

\section{E. Pengujian Sistem}

Peneliti melakukan pengujian sistem dengan metode blackbox testing yang merupakan suatu tehnik pengujian fungsionalitas program, tanpa melibatkan pengetahuan tentang internal aplikasi (source code dan sebagainya) [16]. Berdasarkan dari pengujian black box yang telah dilakukan hasil yang dapat diterima dari pengujian tersebut, maka dapat disimpulkan sistem penerimaan siswa berbasis web yang dibangun oleh peneliti ini sudah memenuhi kebutuhan fungsional tiap-tiap user yang terlibat dalam proses penerimaan siswa ini. Hal ini didukung dengan hasil yang secara fungsional sudah sesuai dengan yang diharapkan, sehingga memungkinkan sistem ini untuk dapat diimplementasikan pada SMK Spes Patriae.

\section{SIMPULAN}

Penelitian ini menghasilkan sebuah sistem penerimaan siswa berbasis web yang dapat meminimalisir kesalahan pencatatan data dan menghindari antrian yang terjadi saat pendaftaran. Namun sistem ini masih memiliki beberapa kekurangan. Sistem ini belum memiliki sistem e-banking dalam transaksinya, belum terhubung langsung dengan sistem data pokok pendidikan (DAPODIK) dan sistem keuangan pembayaran sekolah. Saran untuk peneliti selanjutnya ialah diharapkan dapat membuat sistem ini terhubung langsung dengan sistem DAPODIK supaya mempermudah panitia PMB dalam mengirimkan data peserta didik untuk pendataan nasional. Selain itu, juga diharapkan dapat menghubungkan sistem ini dengan sistem keuangan pembayaran sekolah sehingga pembiayaan pada prosedur penerimaan siswa ini dapat lebih terkoordinasi dengan baik, terlebih ketika fitur e-banking yang langsung terhubung dengan bank ditambahkan.

\section{DAFTAR RUJUKAN}

[1] Pemerintah Indonesia, Undang-undang Republik Indonesia Nomor 20 Tahun 2003 Tentang Sistem
Pendidikan Nasional," Undang-undang Tentang Sistem Pendidikan Nasional. Indonesia, 2003.

[2] Sekertaris Jendral, Statistik Persekolahan SMK 2016/2017. Jakarta: PDSPK Kemdikbud, 2017.

[3] Paroki Santo Lukas Sunter, "Sekolah Katolik Santo Lukas - Sunter TK - SD - SMP - SMA - SMK (Status Disamakan),” PT Masterpage Indonesia, 2016. [Online]. Available: http://parokisantolukas.org/ informasi.php?id=75. [Accessed: 24-Oct-2017].

[4] P. Utomo and D. Ariyanti, "Sistem Informasi Pembayaran dan Pendaftaran Siswa Baru Berbasis Web,” J. SISFOTEK Glob., vol. 4, no. 2, pp. 4-6, 2014.

[5] R. K. Bemile, J. Gborgla, P. O. Mensah, V. Boateng, H. O. Ansa, and E. G. Twum, "Online Registration System (A Case of Methodist University College Ghana)," Int. J. Res. Inf. Technol., vol. 2, no. 9, pp. 321-333, 2014.

[6] N. H. Cahyana, E. Y. Prasetyo, and H. Himawan, "Aplikasi Penerimaan Siswa Baru Berbasis Web (SMK Negeri 3 Yogyakarta)," Telematika, vol. 10, no. 1, pp. $1-8,2013$.

[7] H. Hanafiah, S. Universitas, and S. Buana, "Perancangan Sistem Informasi Penerimaan Siswa Baru Berbasis Web ( Studi Kasus : SMP Plus Babussalam Ban ....,” J. Infotronik, vol. 1, no. 1, 2017.

[8] S. S. Kute and S. D. Thorat, "A Review on Various Software Development Life Cycle (SDLC) Models," Int. J. Res. Comput. Comunnication Technol., vol. 3, no. 7, pp. 776-781, 2014.

[9] A. Nugroho, "Unified Modeling Language," in Perancangan dan Implementasi Sistem Basis Data, Yogyakarta: Andi, 2011, p. 119.

[10] P. Hidayatullah and J. K. Kawistara, "Pengenalan HTML," in Pemrograman Web, Bandung: Informatika, 2014, p. 13.

[11] P. Hidayatullah and J. K. Kawistara, "Pengenalan CSS," in Pemrograman Web, Bandung: Informatika, 2014, pp. 53-54.

[12] Jubilee Enterprise, "Pemrograman Bootstrap untuk Pemula,” Jakarta: Elex Media Computindo, 2016, pp. 1-2.

[13] Rosa and M. Shalahuddin, "DBMS," in Rekayasa perangkat lunak Terstruktur dan Berorientasi Objek, Bandung: Informatika, 2015, pp. 44-45.

[14] B. Sidik, "Pemrograman Web dengan PHP," Bandung: Informatika, 2014, p. 333.

[15] B. Sidik, "Pemrograman Web dengan PHP," Bandung: Informatika, 2014, pp. 4, 10-11.

[16] M. Kumar, S. K. Singh, and R. . Dwivedi, "A Comparative Study of Black Box Testing and White Box Testing Techniques,” Int. J. Adv. Res. Comput. 
Sci. Manag. Stud., vol. 3, no. 10, pp. 32-44, 2015.

[17] J. Valacich and Joey George, "Modern System Analysis and Design," 8th ed., United States of America: Pearson Education, 2017, p. 219.

[18] Rosa and M. Shalahuddin, "Activity Diagram," in Rekayasa perangkat lunak Terstruktur dan Berorientasi Objek, Bandung: Informatika, 2015, pp. 161-163.
[19] Rosa and M. Shalahuddin, "Class Diagram," in Rekayasa perangkat lunak Terstruktur dan Berorientasi Objek, Bandung: Informatika, 2015, pp. 141-147. 